CZASOPISMO INŻYNIERII LĄDOWEJ, ŚRODOWISKA I ARCHITEKTURY JOURNAL OF CIVIL ENGINEERING, ENVIRONMENT AND ARCHITECTURE

JCEEA, t. XXXIV, z. 64 (3/I/17), lipiec-wrzesień 2017, s. 387-396, DOI: 10.7862/rb.2017.131

\author{
Agnieszka GŁUSZKO \\ Lucjan ŚLECCZKA ${ }^{2}$
}

\title{
NUMERYCZNA OCENA NOŚNOŚCI I SZTYWNOŚCI KRÓĆCÓW W DOCZOŁOWYCH POLĄCZENIACH RUR PROSTOKĄTNYCH
}

\begin{abstract}
W pracy przedstawiono metodykę modelowania oraz rezultaty analiz numerycznych nośności i sztywności króćca teowego $(\mathrm{T})$ oraz króćca podwójnie teowego (П). Króciec teowy (T) jest elementem składowym styków doczołowych kształtowników o przekroju poprzecznym otwartym (IPE lub HEB), króciec podwójnie teowy (П) jest zaś fragmentem styku doczołowego rur o przekroju prostokątnym. Zastosowanie metody składnikowej do określania nośności i sztywności połączeń doczołowych z rur prostokątnych wymaga numerycznego i/lub doświadczalnego zbadania zachowania króćców podwójnie teowych (П) i stwierdzenia na ile odbiega ono od dobrze znanego zachowania króćców teowych (T). Rezultaty symulacji zachowania się obu typów króćców skonfrontowano ze sobą. Przeprowadzono analizę parametryczną z uwzględnieniem zmiany grubości blachy czołowej oraz szerokości rozstawu ścianek rury. Wynikiem analiz jest określenie nośności i sztywności oraz występujących form zniszczenia. Porównano je z rezultatami analitycznego określenia tych parametrów przy użyciu metody składnikowej (w ujęciu PN-EN 1993-1-8) i za pomocą innych dostępnych metod obliczeniowych. Przeprowadzone analizy wskazują na możliwość stosowania metody składnikowej w połączeniach doczołowych rur, lecz niezbędne jest jej odpowiednie dostosowanie do takiego podejścia.
\end{abstract}

Słowa kluczowe: śrubowe połączenia doczołowe, metoda składnikowa, króciec teowy, króciec П, metoda elementów skończonych

\section{Wprowadzenie}

PN-EN 1993-1-8 [1] zawiera procedurę obliczania nośności i sztywności śrubowych połączeń doczołowych kształtowników dwuteowych. Niestety, jej wskazania nie mogą być bezpośrednio stosowane do wyznaczania właściwości strukturalnych połączeń doczołowych kształtowników zamkniętych (rur o przekroju prostokątnym). Przede wszystkim wynika to z innych części podstawo-

\footnotetext{
${ }^{1}$ Autor do korespondencji / corresponding author: Agnieszka Głuszko, Politechnika Rzeszowska, Katedra Konstrukcji Budowlanych, ul. Poznańska 2, 35-084 Rzeszów, agluszko@prz.edu.pl

${ }^{2}$ Lucjan Ślęczka, Politechnika Rzeszowska, sleczka@prz.edu.pl
} 
wych występujących w węzłach rur. W szczególności inną postać geometryczną przybiera tzw. króciec teowy, opisujący wzajemną interakcję zginanej blachy czołowej i rozciąganych śrub. W przypadku połączeń kształtowników otwartych taki króciec przybiera kształt litery $\mathrm{T}$ (skąd bierze się jego nazwa), natomiast w doczołowych stykach rur króciec składa się, oprócz zginanej blachy czołowej, z dwu rozciąganych środników odsuniętych od siebie na szerokość rury, i przyjmuje kształt litery „П”, rys. 1.

a)

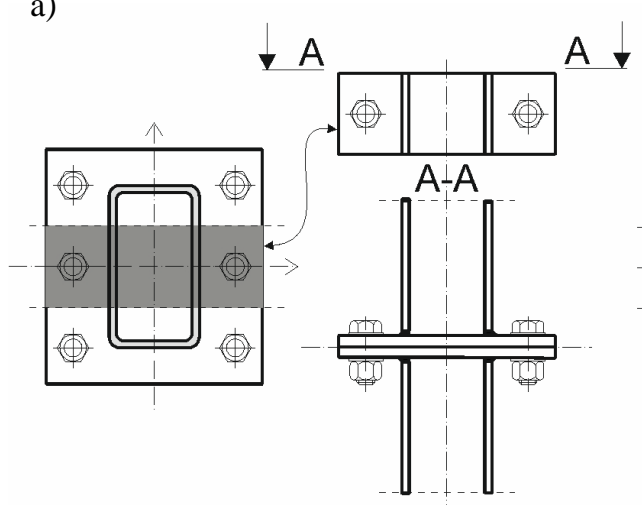

b)

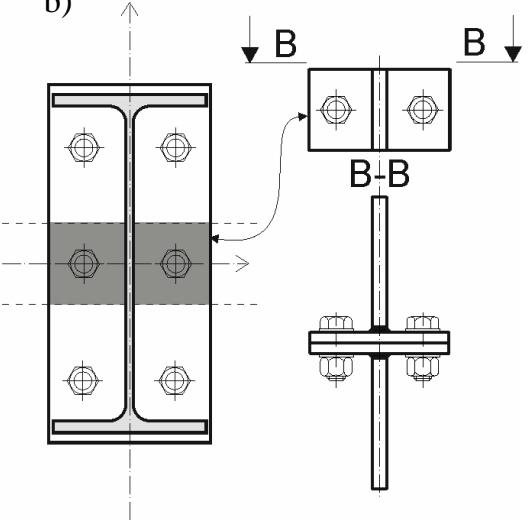

Rys. 1. Króćce połączeń doczołowych: a) króciec podwójnie teowy; b) króciec teowy

Fig. 1. Stubs in end-plate joints: a) П-stub; b) T-stub

Połączenia doczołowe z rur są przedmiotem licznych badań doświadczal-

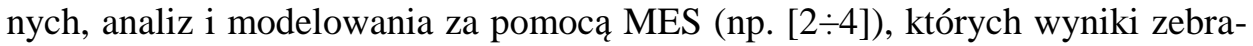
no w przewodnikach do projektowania Design Guide 3 komitetu CIDECT [5] oraz Design Guide 24 instytutu AISC [6]. Wspomniane badania i analizy służyły do opracowania wytycznych analitycznego wyznaczania nośności rozciąganych lub zginanych styków doczołowych, w których śruby rozmieszczono z dwu, lub z czterech przeciwległych stron. Badań i analiz dostosowujących metodykę określania nośności takich węzłów do klasycznej metody składnikowej jest o wiele mniej [7].

W niniejszej pracy przedstawiono analizę nośności i sztywności klasycznego króćca teowego (T) oraz króćca podwójnie teowego (П) o podobnej geometrii, lecz wydzielonego ze styku doczołowego rur. Przeprowadzono ją za pomocą metody elementów skończonych. Zachowanie króćca П uwzględnia sztywność giętną blachy czołowej wewnątrz przekroju rury. W obliczeniach uwzględniono zmienną grubość blachy czołowej oraz zmienną szerokość przekroju łączonych rur. Nośność i sztywność króćców oszacowaną na podstawie powyższych analiz porównano z nośnością obliczoną według PN-EN 1993-1-8 [1] i sztywnością uzyskaną na podstawie publikacji [8]. 


\section{Analiza parametryczna}

W pracy rozpatrywano króćce $\mathrm{T}$ oraz króćce $\Pi$ składające się z dwu środników, będących fragmentami ścianek rury prostokątnej, oraz fragmentu blachy czołowej, (rys. 2.).

Przyjęto szerokość obu typów króćców równą $b=90 \mathrm{~mm}$, co wynika z praktycznego zakresu rozstawów śrub $w$ doczołowych połączeniach rur [5]. Dzięki temu uzyskano postać powstających załomów plastycznych w blasze czołowej w postaci linii prostej. W połączeniu dwu części króćców zastosowano śruby M20 klasy 5.8, niesprężane.

W pierwszym etapie analizy rozpatrywano wpływ grubości blachy czołowej na zachowanie obu typów króćców. Przyjęto jej zmienność w zakresie od $t_{p}=8 \div 35 \mathrm{~mm}$, przy stałym rozstawie środników $(2 a=100 \mathrm{~mm})$. W drugim etapie analizy rozpatrywano wpływ zmiany odległości pomiędzy środnikami króćca $\Pi$ przy stałej grubości blachy czołowej. Parametry geometryczne króćców typu П oraz T poddanych analizie zestawiono w tabeli 1 . i 2.

Tabela 1. Analiza parametryczna króćców П

Table 1. Parametric analysis of the $\Pi$-stubs

\begin{tabular}{|c|c|c|c|c|c|c|c|}
\hline \multicolumn{2}{|l|}{ Symbol króćca } & П.8 & П.12 & П.16 & П.20 & П.25 & П.35 \\
\hline \multirow{3}{*}{$\begin{array}{l}\text { Geometria } \\
\text { połączenia }\end{array}$} & $m[\mathrm{~mm}]$ & \multicolumn{6}{|c|}{40} \\
\hline & $n[\mathrm{~mm}]$ & \multicolumn{6}{|c|}{30} \\
\hline & $b[\mathrm{~mm}]$ & \multicolumn{6}{|c|}{90} \\
\hline Śruby & $d[\mathrm{~mm}]$ & \multicolumn{6}{|c|}{20} \\
\hline \multirow{2}{*}{$\begin{array}{l}\text { Wymiary } \\
\text { środnika }\end{array}$} & $h[\mathrm{~mm}]$ & \multicolumn{6}{|c|}{150} \\
\hline & $t[\mathrm{~mm}]$ & \multicolumn{6}{|c|}{8} \\
\hline \multirow{4}{*}{$\begin{array}{l}\text { Rozstaw } \\
\text { środników }\end{array}$} & \multirow{4}{*}{$2 a[\mathrm{~mm}]$} & 60 & 60 & 60 & 60 & 60 & 60 \\
\hline & & 100 & 100 & 100 & 100 & 100 & 100 \\
\hline & & 180 & 180 & 180 & 180 & 180 & 180 \\
\hline & & 250 & 250 & 250 & 250 & 250 & 250 \\
\hline $\begin{array}{l}\text { Grubość blachy } \\
\text { czołowej }\end{array}$ & $t_{p}[\mathrm{~mm}]$ & 8 & 12 & 16 & 20 & 25 & 35 \\
\hline
\end{tabular}

Tabela 2. Analiza parametryczna króćców T

Table 2. Parametric analysis of the T-stubs

\begin{tabular}{|c|c|c|c|c|c|c|c|}
\hline \multicolumn{2}{|l|}{ Symbol króćca } & T.8 & T.12 & T.16 & T.20 & T.25 & T.35 \\
\hline \multirow{3}{*}{$\begin{array}{l}\text { Geometria } \\
\text { połączenia }\end{array}$} & $m[\mathbf{m m}]$ & \multicolumn{6}{|c|}{40} \\
\hline & $n[\mathrm{~mm}]$ & \multicolumn{6}{|c|}{30} \\
\hline & $b[\mathrm{~mm}]$ & \multicolumn{6}{|c|}{90} \\
\hline Śruby & $d[\mathrm{~mm}]$ & \multicolumn{6}{|c|}{20} \\
\hline \multirow{2}{*}{$\begin{array}{l}\text { Wymiary } \\
\text { środnika }\end{array}$} & $h[\mathrm{~mm}]$ & \multicolumn{6}{|c|}{150} \\
\hline & $t[\mathrm{~mm}]$ & \multicolumn{6}{|c|}{16} \\
\hline $\begin{array}{l}\text { Grubość blachy } \\
\text { czołowej }\end{array}$ & $t_{p}[\mathbf{m m}]$ & 8 & 12 & 16 & 20 & 25 & 35 \\
\hline
\end{tabular}



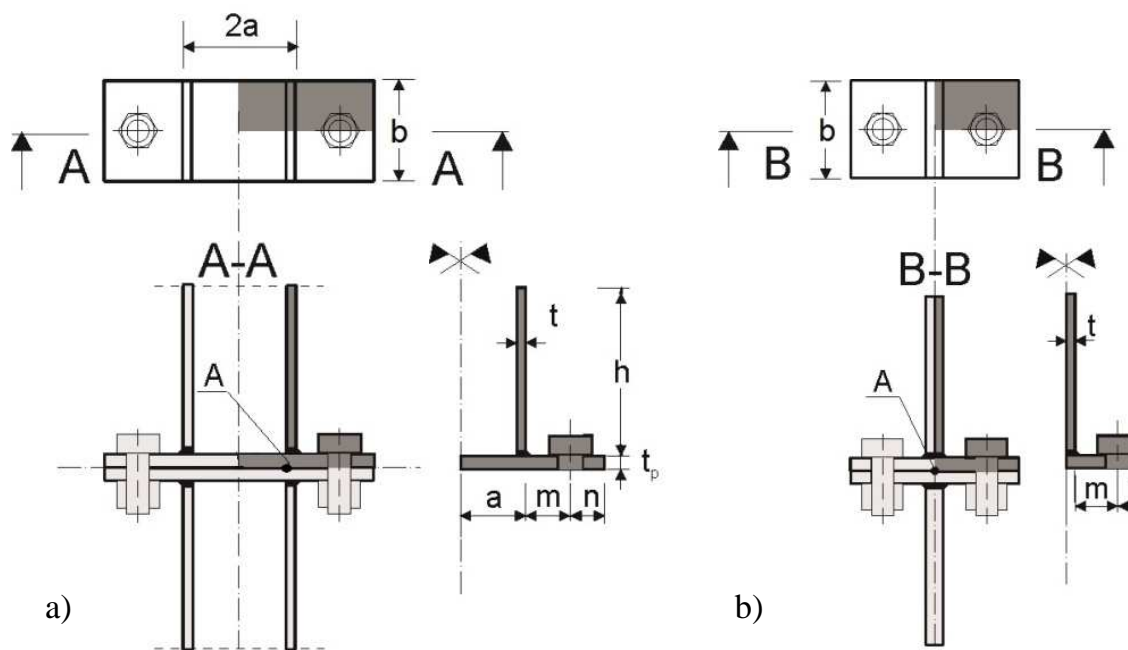

b)

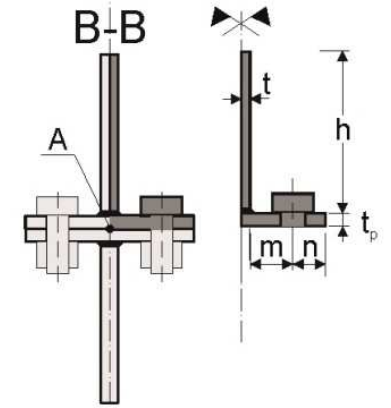

Rys. 2. Charakterystyki geometryczne: a) króciec podwójnie teowy; b) króciec teowy

Fig. 2. Geometrical parameters: a) П-stub; b) T-stub

\section{Modele numeryczne króćców}

Do modelowania użyto pakietu obliczeniowego ADINA [9]. Wykonano modele trójwymiarowe (3D) rozpatrywanych połączeń. Użyto dwudziestowęzłowych elementów skończonych [10]. W obliczeniach uwzględniano 1/8 połączenia z uwagi na symetrię ich kształtu i obciążenia. W płaszczyznach symetrii nadano odpowiednie warunki brzegowe.

W celu ograniczenia liczby powierzchni kontaktu, łeb śruby oraz podkładkę zamodelowano jako jedną bryłę. Zabieg ten nie wpływa znacząco na deformację elementów składowych modelu, co przedstawiano już w literaturze [11]. Zjawiska kontaktowe uwzględniono ( $\mathrm{z}$ pominięciem tarcia) pomiędzy łbem śruby a górną powierzchnią blachy czołowej, trzpieniem śruby a powierzchnią otworu na śrubę oraz pomiędzy powierzchnią dolną blachy czołowej a płaszczyzną odniesienia, będącej poziomą płaszczyzną symetrii króćca.

Przyjęto sprężysto-plastyczny model materiału, wieloliniowy, osobny dla stali gatunku S235 i dla śrub klasy 5.8. Nominalną zależność odkształcenie naprężenie $\sigma-\varepsilon$ przedstawiono na rys. 3. Obliczenia przeprowadzono z uwzględnieniem zasady dużych przemieszczeń i dużych odkształceń, więc zależność $\sigma-\varepsilon$ została przekształcona do zależności $\sigma_{\text {true }}-\varepsilon_{\text {true }}$ przy zastosowaniu opcji obliczeniowych dostępnych w programie ADINA [9].

Obciążenie króćców zamodelowano, jako przemieszczenie przyłożone do górnej powierzchni ścianki środnika. Króćce zaprojektowano tak, aby o ich nośności nie decydowało zniszczenie rozciąganych środników, ani zniszczenie spoin. W przypadku króćca teowego pomiędzy środnikiem a blachą czołową 
zastosowano spoinę czołową typu $\mathrm{K}$, natomiast $\mathrm{w}$ modelu króćca podwójnie teowego spoinę czołową typu V.

a)

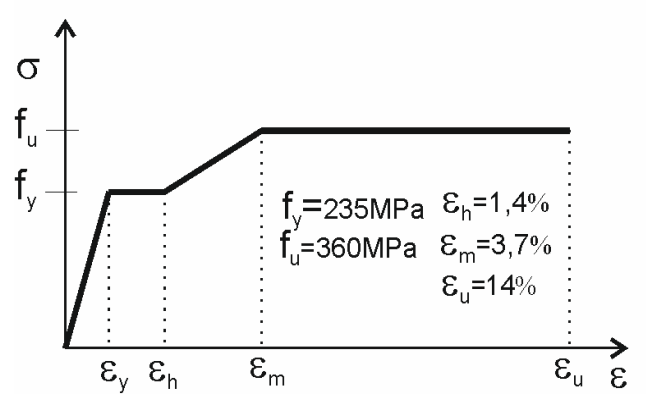

b)

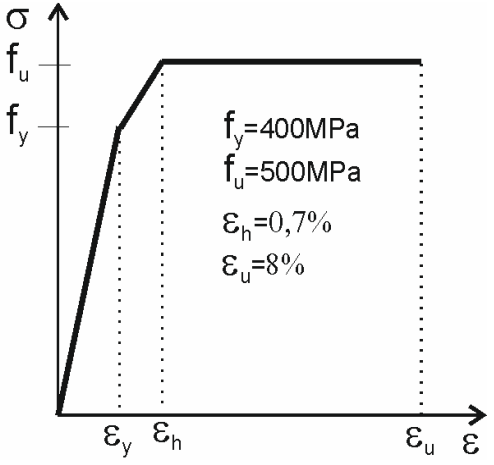

Rys. 3. Nominalne modele materiałowe: a) stal S235; b) śruba klasy 5.8

Fig. 3. Nominal models of materials: a) steel S235; b) bolt 5.8 grade

\section{Wyniki}

Wyniki w postaci statycznej ścieżki równowagi siła-przemieszczenie $(F-\Delta)$ dla króćców teowych i króćców podwójnie teowych (przy rozstawie środników $2 a=100 \mathrm{~mm}$ ), pokazano na rys. 4 .
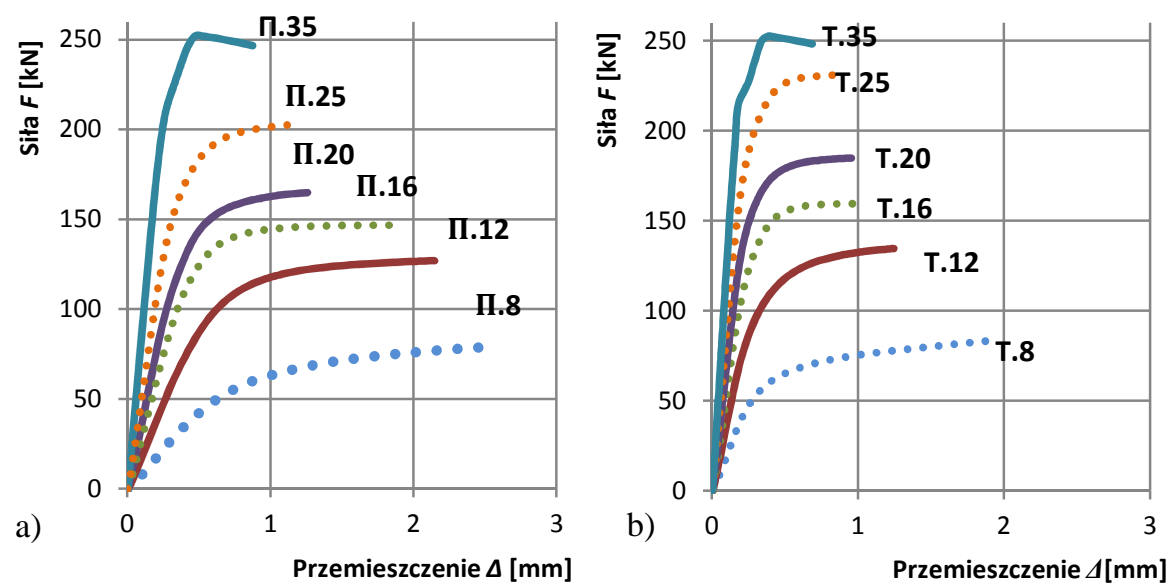

Rys. 4. Statyczne ścieżki równowagi $F-\Delta$ : a) króćców podwójnie teowych; b) króćców teowych Fig. 4. F- $\Delta$ curves: a) П-stub; b) T-stub

Przemieszczenie $\Delta \mathrm{w}$ pokazanych na rys. 4 wykresach, ulegało zwiększeniu pod wpływem obciążenia siłą $F$ i było rejestrowane w punkcie A, (rys. 2.). 
Z otrzymanych zależności $F-\triangle$ wyznaczano sztywność początkową króćców rurowych $S_{j, i n i, \Pi}$ i króćców teowych $S_{j, i n i, T}$, jako tangens kąta nachylenia linii stycznej do charakterystyki $F-\Delta \mathrm{w}$ zakresie sprężystym, przechodzącej przez początek układu współrzędnych. Następnie wyznaczano nośność króćców podwójnie teowych $F_{R k, \Pi}$ i króćców teowych $F_{R k, T}$, jako plastyczną lub graniczną. W przypadku, gdy o nośności decydowało zerwanie śrub, była to nośność graniczna (największa wartość siły uzyskana z zależności siła - przemieszczenie), rys. 4. W przypadku, gdy występowało jedynie uplastycznienie blachy czołowej, bez zerwania śrub, była to nośność plastyczna, wyznaczana w sposób umowny. Jej wartość określa rzędna punktu przecięcia się dwu linii - wychodzącej z początku układu współrzędnych o nachyleniu $S_{j, \text { ini }}$ i drugiej, stycznej do wykresu $F-\Delta$, posiadającej nachylenie $1 / 10 S_{j, \text { ini }}[12]$.

Wyznaczoną tak sztywność i nośność rozpatrywanych modeli króćców zestawiono w tabeli 3-4, i porównano tam z nośnością $F_{R k, T, E C 3}$ oraz sztywnością początkową $S_{j, i n i, T, E C 3}$ wyznaczoną analitycznie według metody składnikowej (w ujęciu PN-EN 1993-1-8 [1]). Zestawione w tabeli wartości nośności i sztywności, zarówno z analiz MES, jak i wzorów analitycznych, odnoszą się już do całych króćców, nie do modelowanych ich fragmentów.

Tabela 3. Nośność analizowanych króćców

Table 3. Resistance of the stubs

\begin{tabular}{|c|c|c|c|c|c|c|c|c|}
\hline Symbol & $\begin{array}{l}F_{R k, I} \\
{[k N]}\end{array}$ & Symbol & $\begin{array}{l}F_{R k, T} \\
{[k N]}\end{array}$ & $\begin{array}{c}F_{R k, T, E C 3} \\
{[k N]} \\
\end{array}$ & $\begin{array}{c}F_{R k, \Pi} \\
/ F_{R k, T} \\
\end{array}$ & $\begin{array}{c}\boldsymbol{F}_{R k, \Pi} \\
/ \boldsymbol{F}_{R k, T, E C 3} \\
\end{array}$ & $\begin{array}{c}\boldsymbol{F}_{\boldsymbol{R} k, T} \\
/ \boldsymbol{F}_{\boldsymbol{R} k, T, E C 3} \\
\end{array}$ & $\begin{array}{c}\text { Model } \\
\text { zniszczenia }\end{array}$ \\
\hline П.8 & 65,1 & T.8 & 61,9 & 51,1 & 1,05 & 1,27 & 1,21 & 1 \\
\hline П.12 & 128,3 & T.12 & 134,5 & 115,1 & 0,95 & 1,11 & 1,17 & $2 a$ \\
\hline П.16 & 144,6 & T.16 & 159,8 & 160,7 & 0,90 & 0,90 & 0,99 & $2 b$ \\
\hline П.20 & 164,9 & T.20 & 185,2 & 184,4 & 0,89 & 0,89 & 1,00 & $3 a$ \\
\hline П.25 & 198,8 & T.25 & 232,1 & 221,3 & 0,86 & 0,90 & 1,05 & $3 a$ \\
\hline I.35 & 241,2 & T.35 & 243,9 & 245,0 & 0,96 & 0,95 & 0,99 & $3 b$ \\
\hline
\end{tabular}

Tabela 4. Sztywność początkowa analizowanych króćców

Table 4. Initial stiffness of the stubs

\begin{tabular}{|c|c|c|c|c|c|c|c|c|c|}
\hline Symbol & $\begin{array}{c}S_{j, i n i, \Pi} \\
{[\mathrm{kN} / \mathrm{mm}]}\end{array}$ & $\begin{array}{r}S_{j, i n i, \Pi,[8]} \\
{[\mathrm{kN} / \mathrm{mm}]}\end{array}$ & Symbol & $\begin{array}{c}S_{j, \text { ini }, T} \\
{[\mathrm{kN} / \mathrm{mm}]}\end{array}$ & $\begin{array}{l}S_{j, i n i, T, E C 3} \\
{[\mathrm{kN} / \mathrm{mm}]} \\
\end{array}$ & $(2) /(3)$ & $(2) /(5)$ & $(2) /(6)$ & $(5) /(6)$ \\
\hline (1) & (2) & (3) & $(4)$ & (5) & (6) & (7) & (8) & (9) & (10) \\
\hline П.8 & 89,1 & 58,0 & T.8 & 212,8 & 200,4 & 1,54 & 0,42 & 0,44 & 1,06 \\
\hline П.12 & 189,6 & 177,7 & T.12 & 387,8 & 545,2 & 1,07 & 0,49 & 0,35 & 0,71 \\
\hline П.16 & 287,3 & 344,2 & T.16 & 590,3 & 884,1 & 0,83 & 0,49 & 0,32 & 0,67 \\
\hline П.20 & 374,0 & 492,8 & T.20 & 740,1 & 1062,8 & 0,76 & 0,51 & 0,35 & 0,70 \\
\hline П.25 & 481,9 & 592,5 & T.25 & 924,9 & 1095,7 & 0,81 & 0,52 & 0,44 & 0,84 \\
\hline П.35 & 699,6 & 587,8 & T.35 & 1299,3 & 952,7 & 1,19 & 0,54 & 0,73 & 1,36 \\
\hline
\end{tabular}

W tabeli 4. zamieszczono także sztywność króćca podwójnie teowego $S_{j, i n i, \Pi,[8]}$ wyznaczoną za pomocą procedury zawartej w pracy [8]. Według niej 
sztywność początkową króćców П można wyznaczyć za pomocą wzorów zamieszczonych w [1], z tym, że współczynniki sztywności zginanej blachy czołowej $k_{5}$ oraz rozciąganych śrub $k_{10}$ oblicza się biorąc pod uwagę fragment blachy czołowej wewnątrz przekroju rury, z zależności:

$$
\begin{aligned}
& k_{5}=\frac{2(3 a+3 m \alpha+n \alpha) l_{e f f, i n i} t_{p}{ }^{3}}{m^{2}\left(3 m^{2} \alpha+4 n m \alpha+12 a m+12 a n\right)} \\
& k_{10}=\frac{4 n(3 a+3 m \alpha+n \alpha) A_{s}}{\left(6 a m+6 a n+3 m^{2} \alpha+2 n^{2} \alpha+6 n m \alpha\right) L_{b}}
\end{aligned}
$$

gdzie: $l_{\text {effini }}=0,85 l_{e f f}-$ długość efektywna blachy czołowej, $t_{p}$ - grubość blachy czołowej, $A_{s}$ - pole powierzchni przekroju czynnego śruby, $L_{b}$ - baza wydłużalności śruby, $a, m, n$-według rys. 2a, $\alpha$-współczynnik uwzględniający zwiększoną sztywność fragmentu blachy czołowej wewnątrz przekroju rury.

W króćcu teowym zaobserwowano trzy mechanizmy zniszczenia opisane w [1]. Mechanizm pierwszy charakteryzuje się uplastycznieniem blachy czołowej w linii śrub i równocześnie wzdłuż brzegu spoiny łączącej blachę czołową ze środnikiem. Drugi mechanizm polega na wystąpieniu uplastycznienie zginanej blachy wzdłuż brzegu spoiny, z jednoczesnym zerwaniem śrub. Mechanizm trzeci jest związany wyłącznie z zerwaniem śrub.

a)

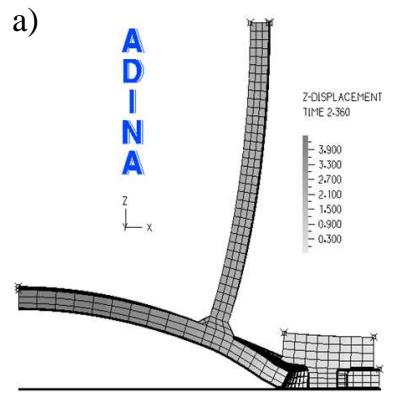

b)

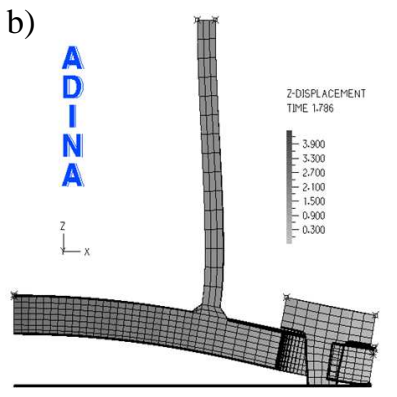

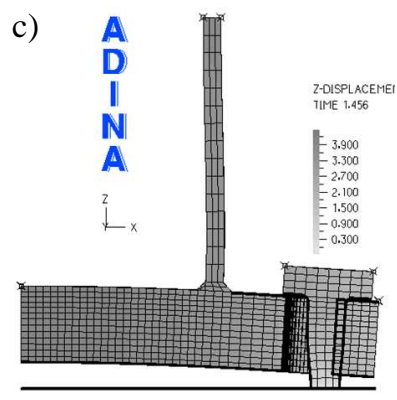

Rys. 5. Deformacja króćca П (2a = 180 mm): a) П.8; b) П.16; c) П.35

Fig. 5. Deformation of $\Pi$-stub $(2 \mathrm{a}=180 \mathrm{~mm})$ : a) П.8; b) П.16; c) П.35

W przypadku króćca podwójnie teowego zaobserwowano, niżej wymienione, pięć modeli zniszczenia:

a) Model 1 - uplastycznienie blachy w osi śrub oraz wzdłuż brzegu spoiny,

b) Model 2a - uplastycznienie blachy w osi śrub i wzdłuż brzegu spoiny oraz zniszczenie śrub czemu towarzyszy efekt dźwigni, 
c) Model $2 b$ - uplastycznienie blachy w osi śrub oraz zniszczenie śrub wraz $z$ efektem dźwigni,

d) Model 3a - zniszczenie śrub wraz z pojawieniem się efektu dźwigni,

e) Model 3b - zniszczenie śrub.

We wszystkich powyższych modelach zaobserwowano zginanie śrub oraz zginanie środnika króćca podwójnie teowego tj. ścianki rury. Pojawienie się obu zjawisk następowało przede wszystkim w króćcach o blachach niewielkiej grubości, $t_{p}=8 \mathrm{~mm}$. W każdym z analizowanych przypadków zaobserwowano zginanie fragmentu blachy wewnątrz przekroju rury, lecz nie nastąpiło jej pełne uplastycznienie. Przykładowe deformacje króćców П przedstawiono na rys. 5.
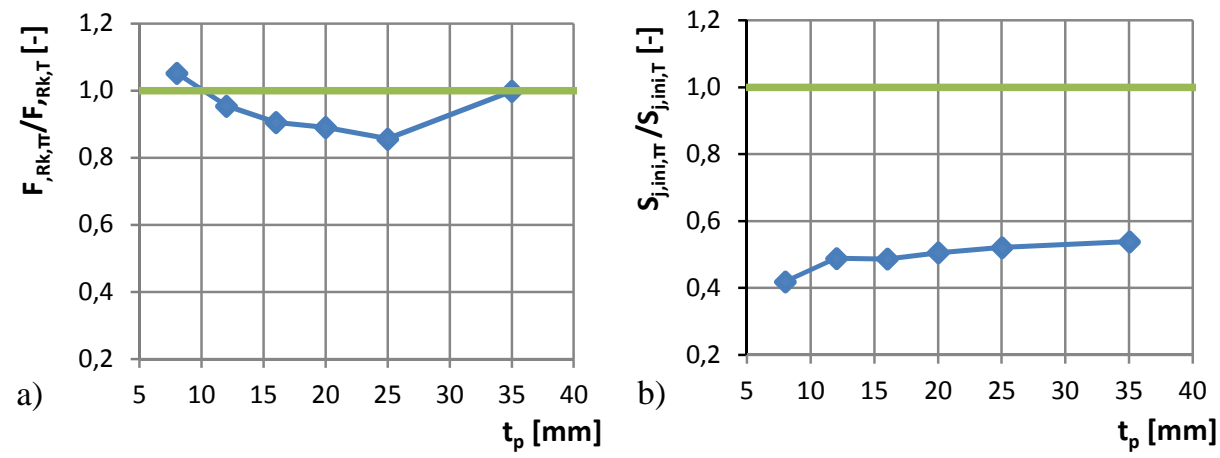

Rys. 6. a) Nośność króćców П w odniesieniu do nośności króćców T; b) Sztywność początkowa króćców П w odniesieniu do sztywności początkowej króćców T

Fig. 6. a) П-stub resistance with reference to T-stub resistance; b) П-stub initial stiffness with reference to T-stub initial stiffness
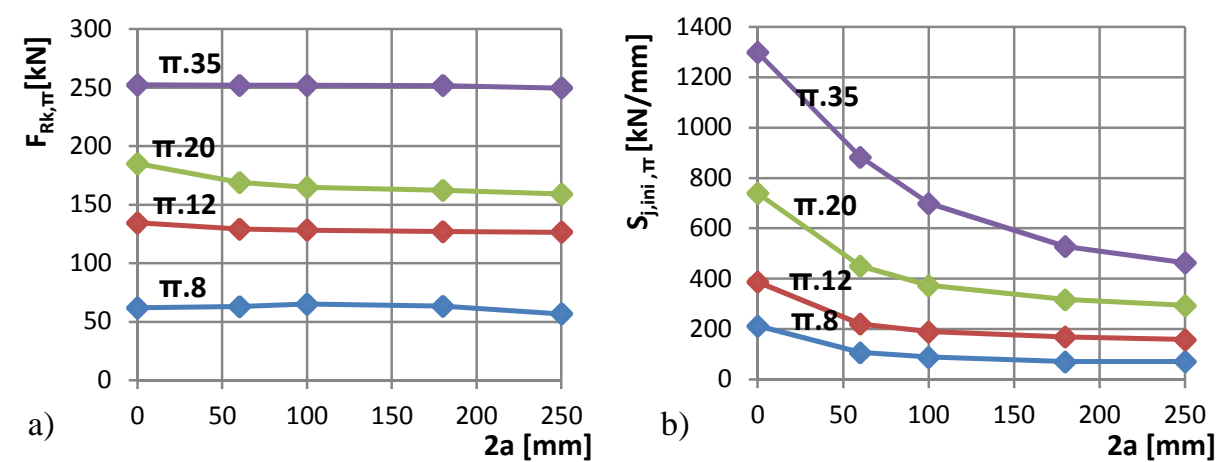

Rys. 7. Właściwości strukturalne króćców П przy zmiennym rozstawie środników 2a: a) nośność; b) sztywność początkowa

Fig. 7. Structural properties of $\Pi$-stub under changing pitch of endplate $2 a$ : a) resistance; b) initial stiffness 
Na podstawie uzyskanych z modelowania MES rezultatów można stwierdzić, że nośność króćców podwójnie teowych jest mniejsza do $14 \%$ od nośności króćców teowych w przypadku interakcji zginania blachy czołowej i zerwania śrub. Gdy pojawiają się pozostałe modele zniszczenia, nośności króćców T i П są zbliżone (rys. 6a). Zastosowanie do określania nośności króćców П metody składnikowej (jak dla króćców T) daje całkiem dobre oszacowania (tabela 3.).

W przypadku porównania sztywności króćców podwójnie teowych do sztywności króćców teowych wyniki są zdecydowanie rozbieżne. Sztywność króćców П uzyskana z obliczeń MES stanowi 42 $\div 54 \%$ sztywności początkowej króćców T (rys. 6b). Ponadto na sztywność króćców podwójnie teowych znacząco wpływa rozstaw ścianek środników. Przedstawione w tabeli 4 sztywności uzyskano dla rozstawu środników $2 a=100 \mathrm{~mm}$. Wyniki drugiego etapu analizy, w którym uwzględniono zmieniający się rozstaw pomiędzy środnikami, w zakresie $2 a=60 \div 250 \mathrm{~mm}$ pokazano na rys. $7 \mathrm{~b}$. Widać tam wyraźnie zmniejszającą się sztywność początkową króćca $\Pi \mathrm{w}$ miarę wzrostu rozstawu ścianek $2 a$, (rys. 7b).

Wzory analityczne zawarte $\mathrm{w}$ [8] służące do określania sztywności początkowej króćców П dają znacząco lepsze oszacowania niż procedura określania sztywności króćca T zawarta w [1].

Zmiana rozstawu środników króćca $\Pi$ nieznacznie wpływa na zmianę ich nośności. Przy cienkich blachach o grubości $t_{p}$ równej $8 \mathrm{~mm}$ nośność zmniejsza się o $11 \%$ wraz ze zwiększeniem szerokości blachy. W pozostałych króćcach różnice wynoszą kilka procent (rys. 7a).

\section{Podsumowanie}

Wyniki przeprowadzonej analizy parametrycznej dowodzą, że istnieje możliwość stosowania metody składnikowej, przeznaczonej dla połączeń doczołowych z kształtowników otwartych, przy obliczaniu nośności połączeń z kształtowników zamkniętych, w których śruby rozmieszczone są z dwu przeciwległych stron ścianek rury.

Podatność blachy czołowej wewnątrz przekroju rury nie wpływa znacząco na nośność tego typu połączeń, ma natomiast poważny wpływ na ich sztywność początkową. Istotne znaczenie przy szacowaniu sztywności początkowej ma również szerokość łączonych kształtowników zamkniętych. Im większa jest szerokość rury, tym sztywność początkowa staje się mniejsza.

Praca przedstawia wyniki badań naukowych dofinansowanych $\mathrm{z}$ dotacji MNiSW na utrzymanie potencjału badawczego.

\section{Literatura}

[1] PN-EN 1993-1-8 Eurokod 3: Projektowanie konstrukcji stalowych - Część 1-8: Projektowanie węzłów. PKN, Warszawa 2006. 
[2] Kato B., Mukai A., Bolted tension flanges joining square hollow section members, CIDECT 8B-82/3 E, Tokyo, 1982.

[3] Willibald, S., Packer, J.A. and Puthli, R.S., Experimental study of bolted HSS flange plate connections in axial tension, Journal of Structural Engineering, ASCE, Vol. 128, No. 3, pp. 328-336, 2002.

[4] Packer J. A., Bruno L., Birkemoe P. C., Limit analysis of bolted RHS flange plate joints, Journal of Structural Engineering, 115 (9), 1989.

[5] Packer J.A., Wardenier J., Kurobane Y., Dutta D., Yeomans N., Design Guide 3 for rectangular hollow section (RHS) joints under predominantly static loading, CIDECT, 2009.

[6] Packer J.A., Sherman D., Lecce M., Design Guide 24 Hollow structural sections connections, American Institute of Steel Construction AISC, Chicago, 2010.

[7] Steige Y., Weynand K., Design resistance of end plate splices with hollow sections, Steel Construction 8, , No. 3, pp. 187-193, 2015.

[8] Karlsen F. T., Aalberg A., Bolted RHS end-plate joints in axial tension. Nordic Steel Construction Conference, Norway, 2012.

[9] ADINA System 9.2.1 Adina R\&D Inc., 2016.

[10] Abidelah A., Numerical analysis of the behavior of steel connection approach and experimental calibration, PhD thesis, Blaise Pascal University, [in French], 2009.

[11] Bursi OS., Jaspart JP., Basic issues in the finite element simulation of extended endplate connections. Computers and Structures, 69, pp. 361-382, 1998.

[12] ECCS Technical Committee 1: Recommended Testing Procedure for Assessing the Behaviour of Steel Elements under Cyclic Loads, 1986, European Convention for Constructional Steelwork, Brussels.

\section{NUMERICAL ASSESSMENT OF STUBS' RESISTANCE AND STIFFNESS IN END-PLATE CONNECTIONS FOR RECTANGULAR HOLLOW SECTION}

\section{S u m m a r y}

The paper describes results of the finite element modeling of two types of stubs in bolted end-plate connections. The first one is the T-stub which is the part of open section joints and second one is the $\Pi$-stub which is the part of rectangular hollow section joints. The investigation is made to compare the behavior and find differences between those stubs and then to use $\Pi$-stub in application of the component method in end-plate joints for rectangular hollow sections. The impact of flange plate thickness and pitch of hollow section wall on resistance and initial stiffness is investigated. The results are compared to the predictions of the component method of EN 1993-1-8 and to the another analytical method. It is shown that the component method can be used to determine the structural properties of rectangular hollow section connections after appropriate adjustment.

Keywords: end-plate joint, component method, T-stub, П-stub, finite element modeling

Przestano do redakcji: 30.05 .2017 r.

Przyjęto do druku: 01.09.2017 r. 